\title{
GROWTH, MORTALITY AND YIELD PER RECRUIT OF RHABDOSARGUS HAFFARA (SPARIDAE) FROM THE SUEZ BAY
}

\author{
Sahar F. Mehanna \\ National Institute of Oceanography and Fisheries, Suez and Aqaba \\ Gulfs Branch, Suez, Egypt.
}

Key words: Sparidae, Rhabdosargus haffara, age, growth, mortality rate, exploitation rate, yield per recruit.

\begin{abstract}
A estimate of the age and growth of Rhabdosargus haffara A collected from the Suez Bay is made by examining the growth increment of their scales. The growth rings showed that $R$. haffara rarely attain more than four years. The Bertalanffy growth parameters were estimated as $\mathrm{K}=0.47^{\circ}, \mathrm{L}_{\infty}=26.79 \mathrm{~cm}$ and $\mathrm{t}_{0}=-0.36$. The mean total mortality coefficient "Z" estimated by two different methods was found to be 1.19 . Natural mortality coefficient " $M$ " was estimated to be 0.29 . Exploitation rate "E" was computed as 0.76 . The yield per recruit was estimated using the model of Beverton and Holt (1957). The results indicatid that the stock of R-haffara in the Suez Bay was overexploited and the fishing mortality coefficient must be reduced by about $40 \%$ to obtain the maximum yield per recruit.
\end{abstract}

\section{INTRODUCTION}

The Suez Bay (Fig. 1) represents a semi-isolated shallow estuary, lying at the northern extremity of the Gulf of Suez at latitude of $29^{\circ} 55^{\circ}$ and longitude of $32^{\circ} 31^{\prime} \mathrm{E}$. The bay is opened to the gulf through most of its southern side and it is connected to the Suez Canal by dredged channel of $24 \mathrm{~m}$ deep (Abdel-Rahman, 1993).

Sparid fishes are an important component of the small-scale fisheries (gill net, trammel net and hand line) in the Northern Gulf of Suez (Suez Bay). The mean annual total catch during the last ten years was about 300 ton of which sparids constitute a mean of about $16.2 \%$. This provides more than $22 \%$ of the gross revenue of the small- 
scale fishery due to their high prices in local markets. They are represented by three species namely, Rhabdosargus haffara, $R$. sarba and Diplodus noct from which $R$. haffara is the most dominant species. The only work found in literature is that of Ahmed and ElGanainy (2000). They authors studied the population dynamics of three sparid species from South Sinai Coast of the Gulf of Suez. In spite of the economic importance of this species, information on its biology and dynamics are very rare and the present paper reports the first study on its age, growth, mortality rates and yield per recruit in the Suze Bay.

\section{MATERIAL AND METHODS}

720 specimens of $R$. haffara ranging from 9 to $24.2 \mathrm{~cm}$ total length were collected from the Suez Bay during the period from May 1999 through April 2000. The total length to the nearest $\mathrm{mm}$ and total weight to the nearest $0.1 \mathrm{~g}$ were recorded for each specimen.

\section{Age Determination}

Scales were used for age determination of $R$. haffara. Scales were removed from the area below the lateral line behind the pectoral fin of the left side of the fish. They were kept in special envelops with full information for further reading. Scales were washed with distilled water and mounted dry between two glass slides. The scales were examined using a measuring projector "LEITZ TP 300 " connected to an electronic reversible counter LEITZ VRZ U. The total scale radius and the radius of each annulus were measured to the nearest 0.001 $\mathrm{mm}$. The position of the last ring on each scale was also recorded.

The radius of each scale was plotted against the total length to determine the body length-scale radius relationship. The lengths of the previous ages were back - calculated using Lee's equation (1920).

\section{Length-Weight Relationship}

The relationship between total fish length in $\mathrm{cm}(\mathrm{L})$ and total weight in gram (W) was computed by using the power equation $W=a L^{b}$ where $a \& b$ are constants whose values were estimated by inc least squares method.

\section{Theoretical Growth}

The von Bertalanffy growth model was applied to describe the theoretical growth of $R$. haffara. The constants of the von Bertalanffy 
model $\left(L_{\infty} \& K\right)$ were estimated using the method of Chapman (1960),

While " $\mathrm{t}_{0}$ " was estimated by undertaking linear regression between age $(t)$ and $\ln \left(\mathrm{L}_{\infty}-\mathrm{L}_{\mathrm{t}} / \mathrm{L}_{\infty}\right)$ where $\mathrm{L}_{\mathrm{t}}$ is the length at age $\mathrm{t}$ (Gulland, 1969).

\section{Mortality Rates}

Total mortality coefficient " $Z$ "

The total mortality coefficient was estimated using two different methods, the first is based on the analysis of age composition data (the method of Robson \& Chapman, 1961) and the second is based on the analysis of length frequency data (the method of linearized length converted catch curve of Pauly, 1983).

Natural mortality coefficient " $M$ "

The natural mortality coefficient was computed using the formula suggested by Ursin (1967) as follows: $M=W^{-1 / 3}$ where $W$ is the total weight of fish.

Fishing mortality coefficient " $F$ "

The fishing mortality coefficient was calculated as $F=Z-M$

Exploitation rate " $E$ "

The exploitation rate was estimated using the formula of Gulland (1971) as follows: $E=F / Z$.

Yield per Recruit "Y/R"

The yield per recruit was estimated using the model of Beverton and Holt (1957) by applying the formula of Marten (1978) as follows:

$\mathrm{Y} / \mathrm{R}=\mathrm{F} \mathrm{A} \mathrm{W}_{\infty}\left[(1 / \mathrm{Z})-(3 \mathrm{U} / \mathrm{Z}+\mathrm{K})+\left(3 \mathrm{U}^{2} / \mathrm{Z}+2 \mathrm{~K}\right)-\left(\mathrm{U}^{3} / \mathrm{Z}+3 \mathrm{~K}\right)\right]$

Where $U=1-\left(\mathrm{L}_{\mathrm{c}} / \mathrm{L}_{\infty}\right)$

$A=\left[\left(L_{\infty}-L_{c}\right) /\left(L_{\infty}-L_{r}\right)\right]^{M / k}$

$\mathrm{Lc}=$ length at $1^{\mathrm{st}}$ capture

$\mathrm{Lr}=$ length at recruitment

\section{RESULTS AND DISCUSSION}

\section{Age Determination}

Reliable age determinations are essential for almost all aspects of fishery research but especially for studies of growth, production, population structure and dynamics. A total of 720 scales of fishes ranging from 9 to $24.2 \mathrm{~cm}$ total length were read and used in the 
estimation of the parancters of the growth models. The results revealed that the maximum life span of $R$. haffara is four years. Ahned and Ei-Ganainy (2000) determined the maximum age of $R$. Raffara, $R$ sarioa and Diplodus noct from Southern Sinai Coast and fomd that $R$. haffurateaches thice years old while the longevity of $R$. sarba and Diplodus noct was three and four years, respectively.

Validity of scales of $\boldsymbol{R}$. Iufffora for age determination

1 -Analysis of the recorded marginal growth indicates that one annulus is formed each year as shown in Figure 2.

2- The increase in the size of fish is accompanied by an increase in the number of annuli on the scale. Hence, the scales of larger fish show inore annuli than those of smaller ones.

3- The close agreement between calculated and observed lengths at any age group is an additional evidence of the validity of the annulus as a true year mark.

4- Samples examined during February have true annuli on the marginal region or close to it. Samples collected from March to the following January show variation in the marginal growth of the scale. The marginal increment increases progressively from March till January of the next year, where the highest value recorded.

5 - There is a relation between the type of circuli and season of growth. Narrow bands of circuli have been found at the margin during winter period, while the broader bands of circuli have been found at the margin during the summer period.

\section{Time of annulus formation}

Observation of the position of the last complete ring on the scale shows that most of the fish caught during February had a complete ring close to the scale margin. The time of annulus formation on the scale of $R$. haffara is detected by the examination of the scales collected through the different months of the year. The distance between the last annulus to the scale margin was measured. This distance represents the increment of the scale growth from the time of the formation of the last annulus. Thus, for a certain age group the least increment is considered as the time of annulus formation.

Figure (2) represents the mean values of the scale growth increment of $R$. haffara for age group II through the different months of the year. From this figure it is clear that the least value for the distance between the last annulus to the scale margin occurred during February $(0.055 \mathrm{~mm})$. This means that in $R$. haffara, growth rings were laid down during February. 


\section{Growth in Length}

\section{Body length-scale radius relationship}

The result of a plot of scale radius against total length is shown in Fig. 3. It is obvious from the figure that a linear relationship exists between the radius of the scale and the body length and can be expressed as follows:

$\mathrm{L}=2.4057+3.5197 \mathrm{~S} \quad(\mathrm{r}=0.9895)$

Where $\mathrm{L}$ is the total length in $\mathrm{cm}$ and $\mathrm{S}$ is the scale radius in $\mathrm{mm}$. Ahmed and El-Ganainy. (2000) estimated the total length-scale radius relationship for $R$. haffara from South Sinai Coast as follows: $\mathrm{L}=4.1555+0.1077 \quad(\mathrm{r}=0.8448)$

\section{Back-Calculations}

The fish length at the end of each year of life were backcalculated using the following equation:

$\mathrm{L}_{\mathrm{n}}=(\mathrm{L}-2.4057) \mathrm{S}_{\mathrm{n}} / \mathrm{S}+2.4057$

Where $L_{n}$ is the calculated length at the end of $n$th year, $L$ is the length at capture, $S_{n}$ is the scale radius to $n^{\text {th }}$ annulus and $S$ is the total scale radius.

The modal lengths corresponding to the various ages of $R$. haffara are given in Table 1 . The results showed that $R$. haffara attained their highest growth rate in length at the end of the first year of life $(12.7 \mathrm{~cm})$, after which a gradual decrease in growth increment was noticed with further increase in age (Fig. 4). Ahmed and ElGanainy (2000) found that $R$. haffara from South Sinai Coast of the Gulf of Suez reached a total length of $10.5 \mathrm{~cm}$ at the end of the first year of life, $16.21 \mathrm{~cm}$ at the end of the second year and $19.33 \mathrm{~cm}$ at the end of the third year of life. It is obvious that $R$. haffara in the Suez. Bay are characterized by a higher growth rate in length than those from South Sinai Coast where they attain 12.7, 17.8,21.6 and $23.3 \mathrm{~cm}$ total length at the end of $1^{\text {st }}, 2^{\text {nd }}, 3^{\text {rd }}$ and $4^{\text {th }}$ year of life, respectively.

\section{Length-weight relationship}

The measurements of total length and total weight of 720 specimens of $R$. haffara were used to estimate the length-weight relationship (Fig. 5). The total length ranged between 9 and $24.2 \mathrm{~cm}$ while the total weight varied from 10 and $207 \mathrm{~g}$. The obtained equation was found to be:

$\mathrm{W}=0.01742 \mathrm{~L}^{2.94013} \quad(\mathrm{r}=0.996)$ 


\section{Growth in weight}

The calculated weights for each year of life were computed by applying the corresponding length - weight relationship to the estimated lengths (Tabie 2). It was obvious that, the growth in weight was very slow during the first year of life and the annual growth increment increased with the increase in age until it reaches its maximum value at age group III after which a drop in the growth increment in weight was noticed in the fourth year of life (Fig. 6).

\section{Mathematical description of growth}

The mathematical description of growth is of vital importance $\mathrm{i}_{i \mathrm{i}}$ the field of fisheries management, since the obtained growth parameters ( $\mathrm{L}_{\infty}, \mathrm{K}$ and $\mathrm{t}_{0}$ ) are the basic inputs of various models used for assessing the status of an exploited stock. The most frequently used model is that of von Bertalanffy (1938) which can be represented by the following equation:

$$
\mathrm{L}_{\mathrm{t}}=\mathrm{L}_{\infty}\left(1-\mathrm{e}^{-\mathrm{K}(\mathrm{t}-\mathrm{t} 0)}\right)
$$

where $L_{t}$ is the total length at age $t$,

$\mathrm{L}_{\infty}$ is the asymptotic length,

$\mathrm{K}$ is the growth coefficient

$t_{0}$ is the age at which length is theoretically zero.

In the present study, the growth parameters of the von Bertalanffy growth model were estimated by applying the following equation of Chapman (1960):

$L_{t+1}-L_{t}=L_{\infty}\left(1-e^{-K}\right)-\left(1-e^{-K}\right) L_{t}$

By plotting $L_{t+1}-L_{t}$ against $L_{t}$ a linear relationship is obtained (Fig. 7). This relationship has a slope $" b "=\left(1-e^{-K}\right)$ and an intercept "a" $=-\ln (1-b)$, then $\mathrm{K}=-\ln \mathrm{b}$ and $\mathrm{L}_{\infty}=-\mathrm{a} / \mathrm{b}$. The resultant von Bertalanffy growth equations for $R$. haffara from Suez Bay were:

For growth in length: $L_{t}=26.79\left(1-\mathrm{e}^{-0.47(t+0.36)}\right)$

For growth in weight: $\mathrm{W}_{\mathrm{t}}=275\left(1-\mathrm{e}^{-0.47(\mathrm{t}+0.36)}\right)^{2.94}$

\section{Mortality Rates}

\section{Total mortality coefficient " $Z$ "}

Total mortality coefficient " $Z$ " was estimated by two different methods, Robson \& Chapman (1961) and Pauly (1983) and the obtained results were as follows:

$Z=1.16$ year $^{-1}$ ( Robson\& Chapman, 1961)

$Z=1.22$ year $^{-1}$ (Pauly, 1983) (Fig. 8) 
The obtained results indicated that both values of $Z$ are very close to each other which may indicate the validity of the methods used in age determination.

\section{Natural mortality coefficient "M"}

The formula suggested by Ursin (1967) was applied to estimate the natural mortality coefficient $M$. This formula depends on the presence of relationship between the size and weight of fish and natural mortality. The obtained results showed that the natural mortality coefficient of $R$. haffara was found to be 0.29 year $^{-1}$.

\section{Fishing mortality coefficient "F"}

The fishing mortality coefficient " $F$ " was computed using the relationship $Z=F+M$. The value of $F$ was 0.9 year $^{-1}$.

\section{Exploitation rate "E"}

The exploitation rate "E" of $R$. haffara was found to be 0.76 . This value is high indicating that the stock of $R$. haffara is overexploited.

\section{Yield per Recruit "Y/R"}

The effect of fishing pattern on the abundance of R-haffara stock in Suez Bay was studied through the catch - age composition by applying the model of Beverton and Holt, (1957). In the present study the input parameters used in the calculations were as follow:

$L_{\infty}=26.79 \mathrm{~cm} \mathrm{~W}_{\infty}=275 \mathrm{~g} \mathrm{~K}=0.47$ year $^{-1}$ to $=-0.36$ year $^{-1}$ $\mathrm{L}_{\mathrm{r}}=9 \mathrm{~cm} \mathrm{Lc}=$ variable $\mathrm{M}=0.29$ year $^{-1} \mathrm{Z}=1.19$ year $^{-1} \mathrm{~F}=$ variable

The yield per recruit of $R$. haffara was estimated by Marten's formula (1978) and it was graphically represented in Figure 9. The results indicate that, the yield per recruit was zero when fishing mortality was zero. The increase of fishing mortality is associated with an increase in yield per recruit until it reaches its maximum value then, the yield per recruit decreases whatever the fishing mortality increased. The results indicated also that the present level of fishing mortality coefficient $(F=0.9)$ and length at first capture $\left(\mathrm{L}_{\mathrm{c}}=\right.$ $11.5 \mathrm{~cm}$ ) give a $\mathrm{Y} / \mathrm{R}$ of $43.99 \mathrm{~g}$. The results showed also that the maximum $Y / R$ was obtained at fishing mortality coefficient equal to 0.5 . This means that the present level of fishing mortality coefficient is higher than that which gives the maximum $Y / R$ and it must be reduced by about $44 \%$ to obtain the maximum yield per recruit. 
To investigate the influence of length at first capture $\left(L_{c}\right)$, which is closely related to the estimation of the optimum mesh size, on the yield pei recruit, different values of $L_{c}$ were applied. The results (Fig. 9) showed that the yield per recruit increases when $L_{c}$ increases and the maximum. $Y / R$ for $L_{c}=11.5,13.5,15.5$ and $17.5 \mathrm{~cm}$ was found to be $48.15,51.97,55.97$ and $60.42 \mathrm{~g}$ at fishing mortalities equal to $0.5,0.5,0.6$ and 1 respectively. This means that the present level of $L_{c}$ is not appropriate for the stock of R-haffara in Suez Bay and it must be raised to about $17.5 \mathrm{~cm}$.

From the above mentioned results, it is evident that the stock of R- haffara in the Suez Bay is in a situation of overexploitation and if the reduction of the fishing mortality coefficient which is closely related to the fishing effort is not possible for socio-economic reasons, the length at first capture must be raised from 11.5 to about $17.5 \mathrm{~cm}$.

\section{REFERENCES}

Abdel-Rahman. N. S., (1993). Ecological studies on the zooplankton distribution in the northern part of the Gulf of Suez (Suez Bay). M.Sc. Thesis, Fac. Sci, Suez Canal Univ. 365 pp.

Ahmed, A. I. and A. El-Ganainy, (2000). On the population dynamics of three sparid species from south Sinai coast of the Gulf of Suez. Red Sea. Egypt. J. Aquat. Biol. \& Fish., 4(4): 235-264.

Bertalanffy, L. von, (1938). A quantitative theory of organic growth (Inquiries on growth laws. 2). Hum. Biol., 10: 181-213.

Beverton, R. J. H. and Holt, S. J.(1957). On the dynamics of exploited fish population. U.K. Min. Agr. Fish. Food, Ish. Invest., 19: $533 \mathrm{pp}$.

Chapman, D. G., (1960). Statistical problems in dynamics of exploited fisheries populations. Proc. $4^{\text {th }}$ Berkeley Symp. Math. Stat. and Probability. Cont. Biol. and Probl. Med., 4: 153-168.

Gulland, J. A. (1969). Manual of methods for fish stock assessment. Part 1 Fish population analysis.FAO Man.Fish.Sci., 4: 154 pp. 
Growth, mortality and yield per recruit of Rhabdosargus 39 haffara (Sparidae) from the Suez Bay

Gulland, J. A. (1971). The Fish Resources of the Ocean. West Byfleet. Surrey, Fishing News Books, Ltd.. for FAO, 255 pp.

Lee, R. M. (1920). A review of the methods of age and growth determination in fishes by means of scales. Fish Invest. Min. Agr. Fish., Ser. 2, 4 (2): 1-32.

Marten, G. G. (1978). Calculating mortality rates and optimum yields from length samples. J. Fish. Res. Board. Can., 35 (2): 197201.

Pauly, D. 1983. Some simple methods for the assessment of tropical fish stocks. FAO Fish. Tech. Pap., 234: 52 P.

Pauly, D. (1983a). Length-converted catch curves. A powerful tool for fisheries research in the tropics. Part 1. ICLARM Fishbyte, 1 (2): 9-13.

Robson, D. S. and Chapman, D. G. (1961). Catch curves and mortality rates. Trans. Am. Fish. Soc., 90 (2): 181-189.

Ursin, E. (1967). A mathematical model of some aspects of fish growth, respiration and mortality. J. Fish. Res. Bd. Can., 24: 2355-2453. 
Table (1). Mean back-calculated lengths (cm) of Rhabdosargas serigara from Suez Bay.

\begin{tabular}{|c|c|c|c|c|c|c|}
\hline \multirow[t]{2}{*}{$\begin{array}{l}\text { Age } \\
\text { group }\end{array}$} & \multirow[t]{2}{*}{$\begin{array}{l}\text { No. of } \\
\text { fish }\end{array}$} & \multirow[t]{2}{*}{$\begin{array}{l}\text { Empirical } \\
\text { length }\end{array}$} & \multicolumn{4}{|c|}{$\begin{array}{c}\text { Back-calculated lengths at the end of each } \\
\text { year of life }\end{array}$} \\
\hline & & & 1 & 2 & 3 & 4 \\
\hline 1 & 417 & 13.6 & 12.70 & & & \\
\hline II & 198 & 18.7 & 12.58 & 17.80 & & \\
\hline III & 38 & 22.2 & 12.45 & 17.79 & 21.60 & \\
\hline IV & 9 & 23.9 & 12.37 & 17.66 & 21.41 & 23.30 \\
\hline
\end{tabular}

Table (2). Calculated weights (g) of Rhabdosargus haffara from Suez Bay.

\begin{tabular}{|c|c|c|c|c|c|c|}
\hline \multirow{2}{*}{$\begin{array}{c}\text { Age } \\
\text { group }\end{array}$} & $\begin{array}{c}\text { No. of } \\
\text { fish }\end{array}$ & \multirow{2}{*}{$\begin{array}{c}\text { Empirical } \\
\text { weight }\end{array}$} & \multicolumn{4}{|c|}{ Calculated weights at the end of each } \\
\cline { 4 - 7 } & & & $\mathbf{1}$ & 2 & 3 & 4 \\
\hline & & & & & & \\
I & 417 & 37.48 & $\mathbf{3 0 . 6 5}$ & & & \\
II & 198 & 95.59 & 29.80 & $\mathbf{8 2 . 6 9}$ & & \\
III & 38 & 158.31 & 28.91 & $\mathbf{8 1 . 4 6}$ & $\mathbf{1 4 6 . 0 5}$ & \\
IV & 9 & 196.66 & 28.36 & 80.79 & 142.31 & $\mathbf{1 8 2 . 5 0}$ \\
& & & & & & \\
\hline
\end{tabular}




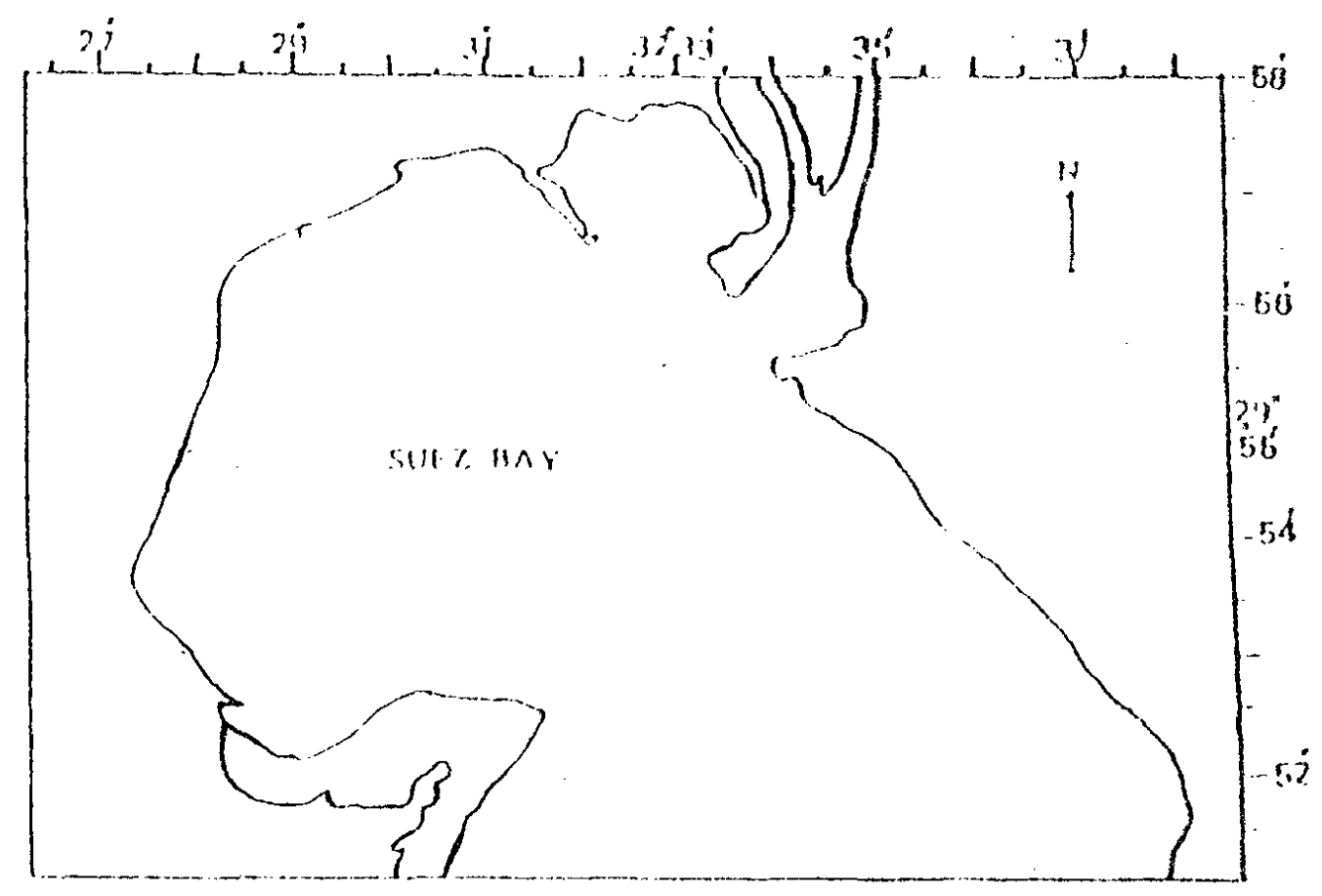

Fig. (1) Suez Bay.

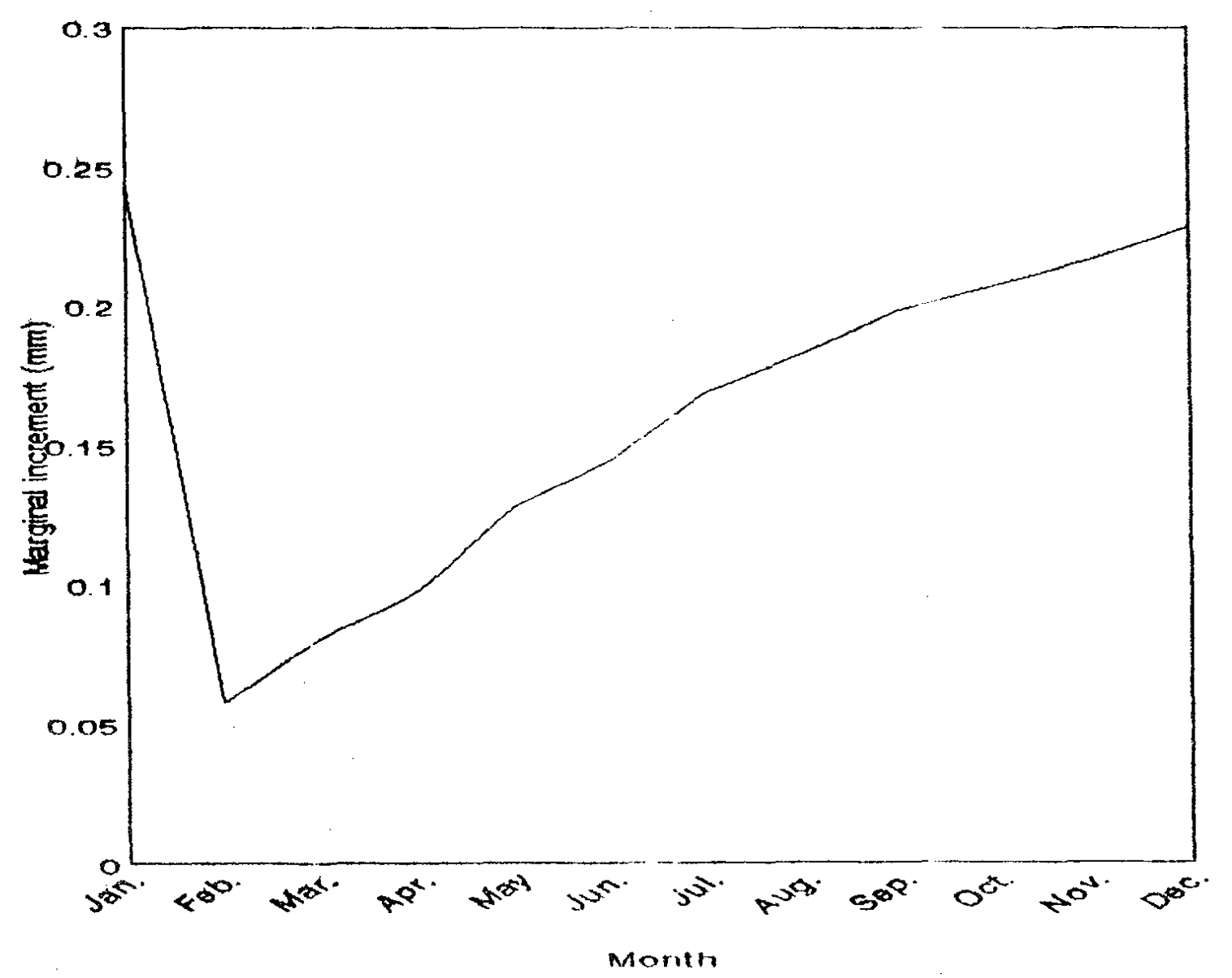

Fig.(2). Time of annulus formation of Ahabdosargus haffara from Suez Bay 


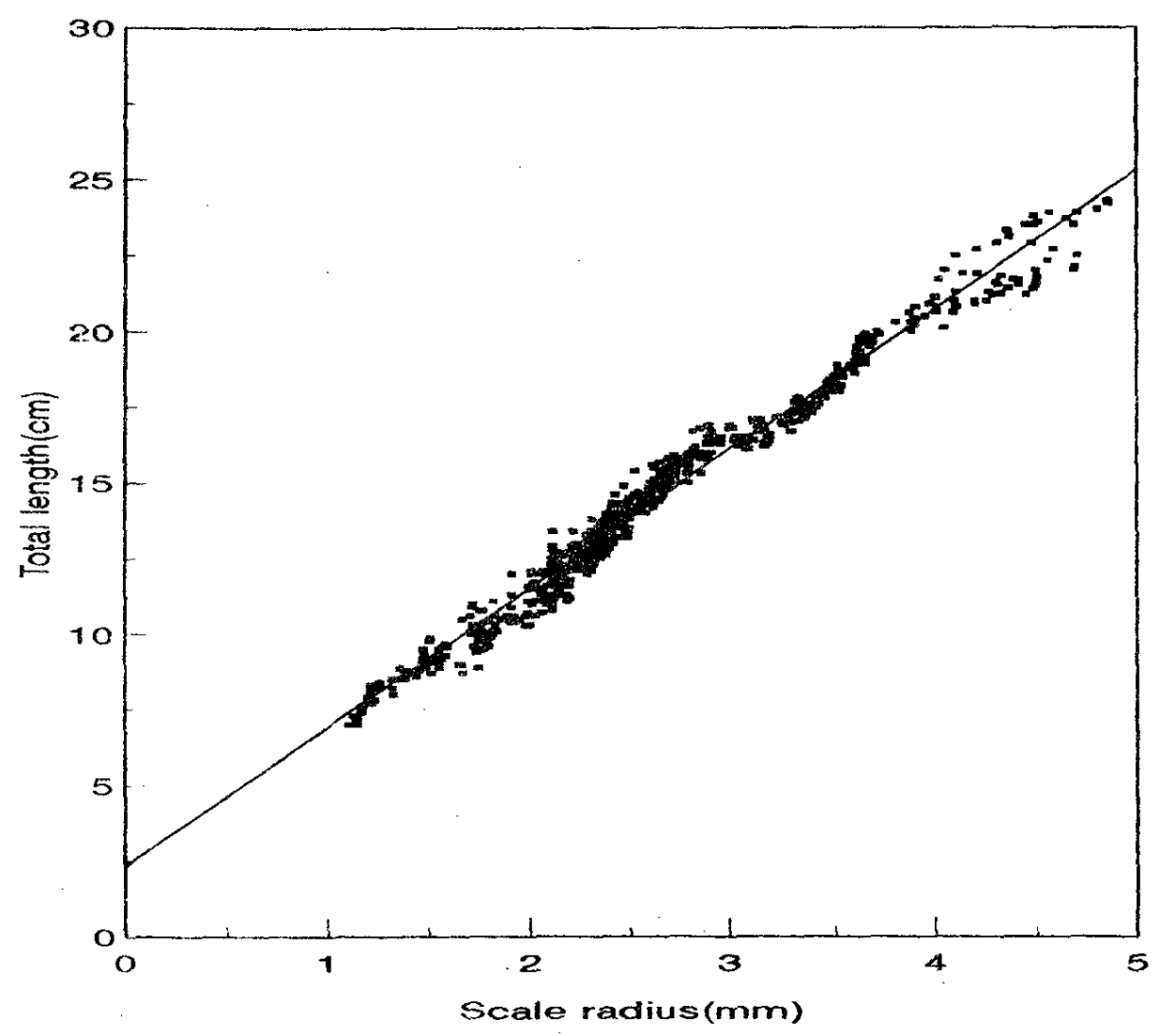

Fig. (3).Total length-scale radius relationship of $R$ habdosargus haffara from Suez Bay.

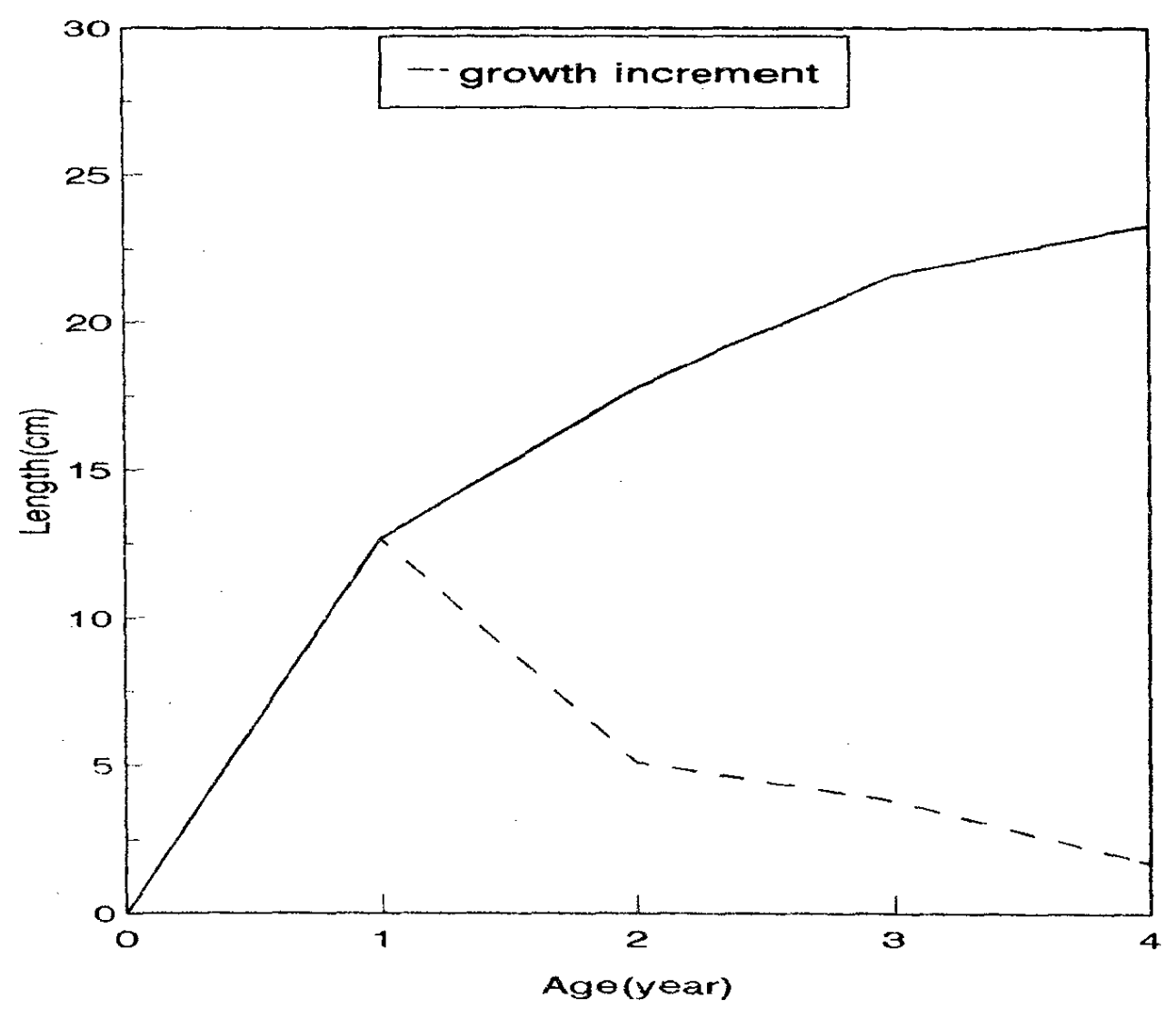

Fig.(4).Growth in length and growth increment of Rhabdosargus haffara from Suez Bay 


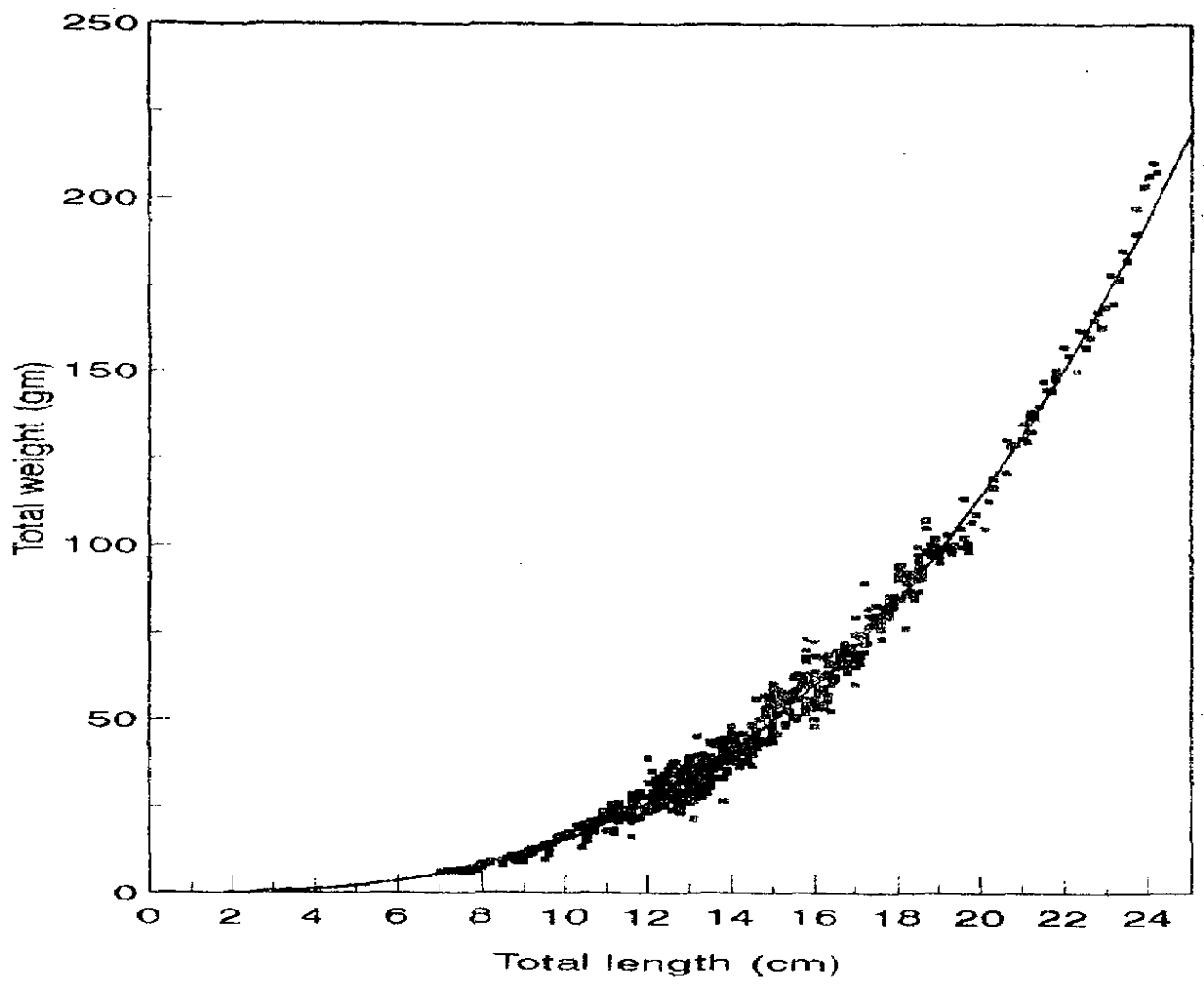

Fig. (5).Length-weight relationship of Rhabdosargus haffara from Suez Bay.

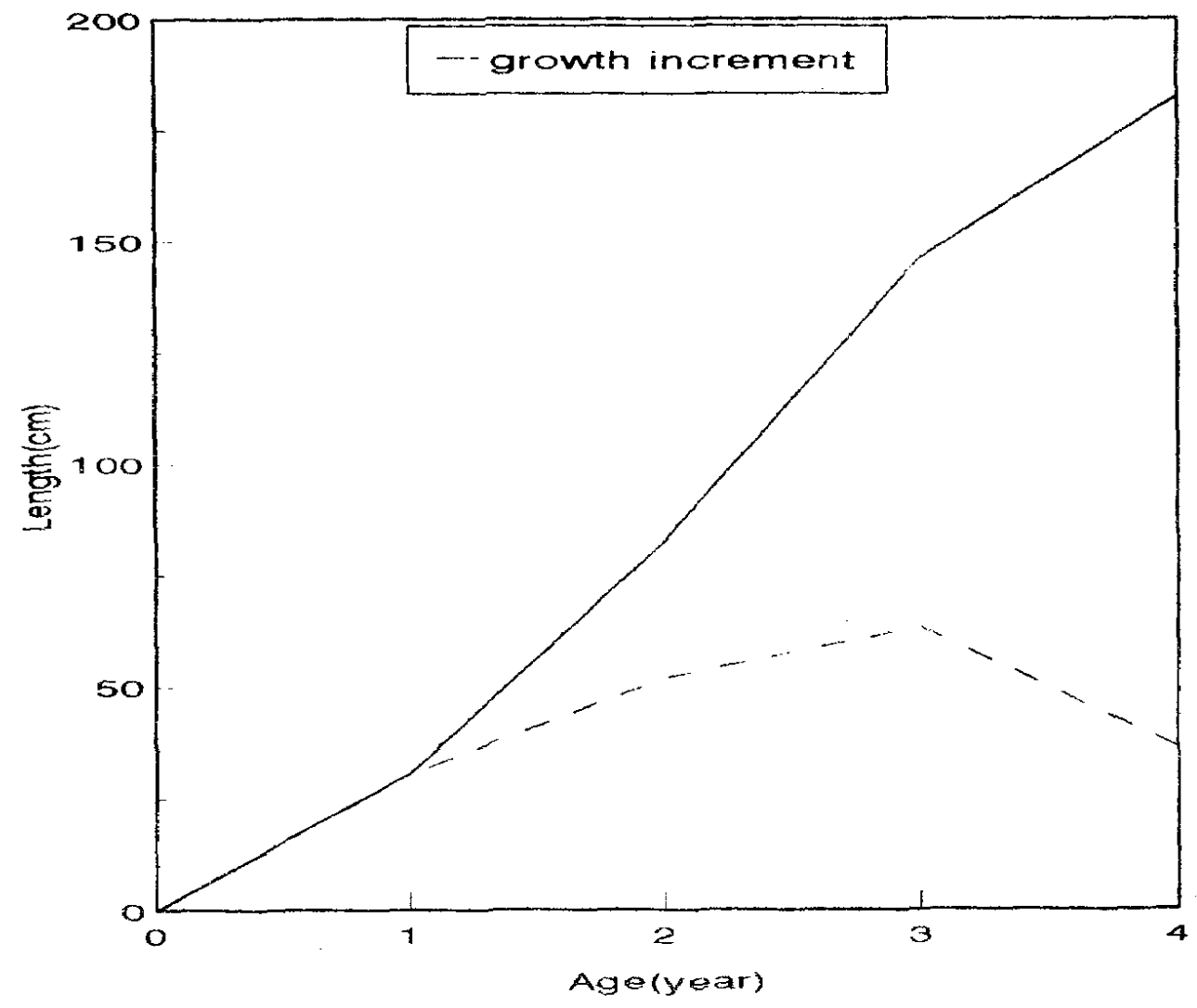

Fig. (6). Growth in weight and growth increment of Rhabdosargus haffara from Suez Bay. 


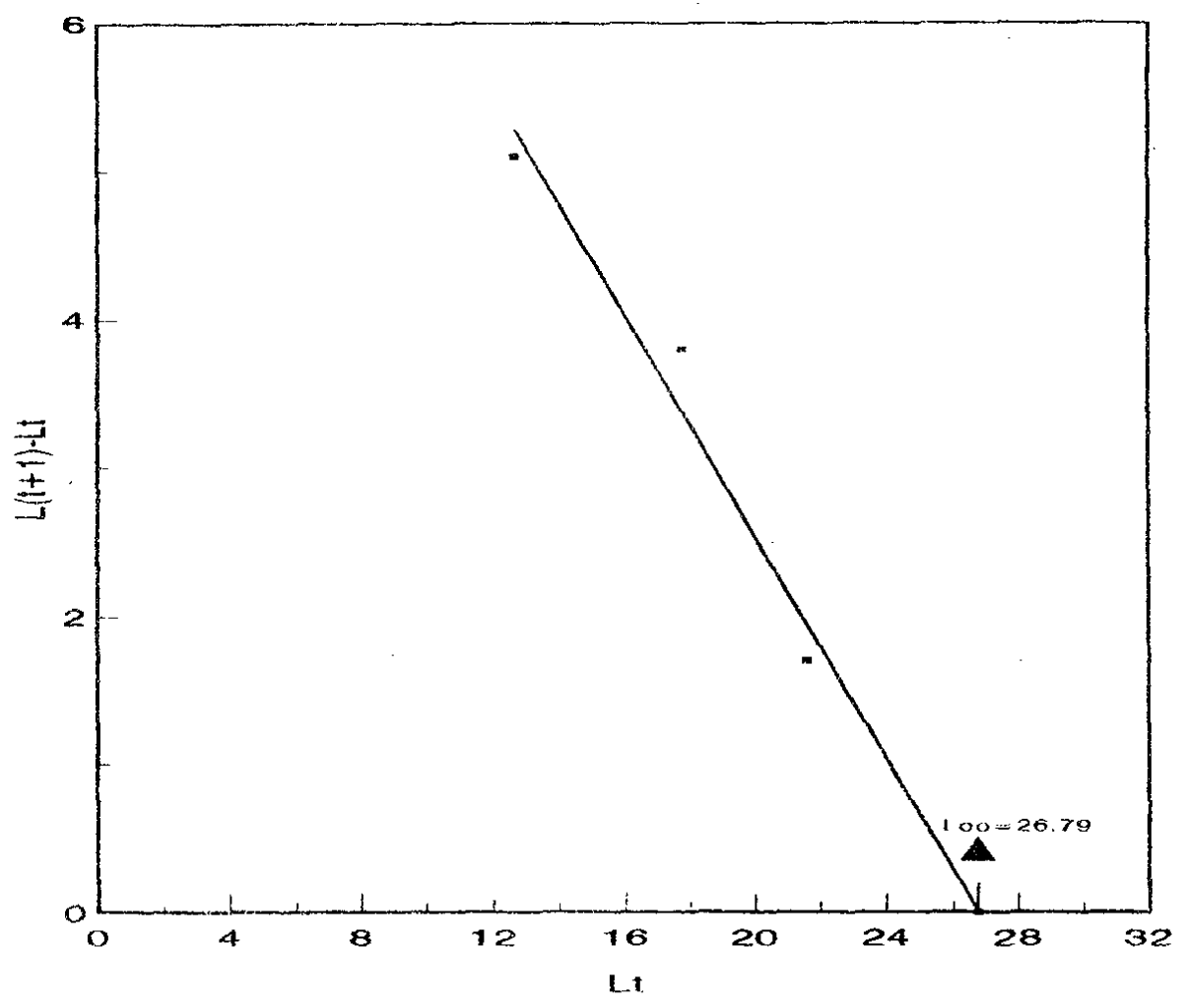

Fig.(7). Chapman's plot for estimating the growth parameters of Rhabdosargus haffara from Suez Bay.

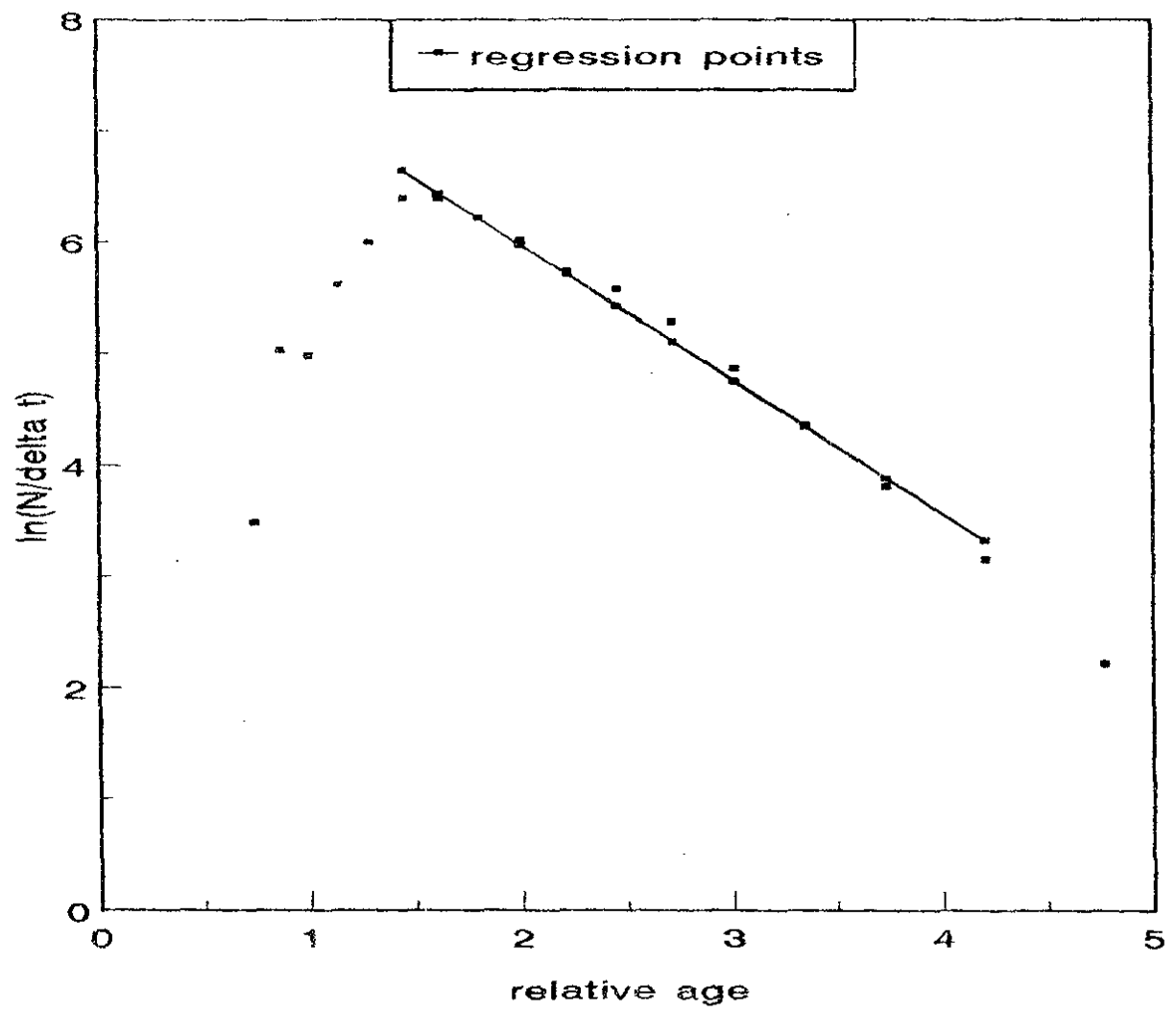

Fig. (8). Estimation of " $Z$ " of Ahabdosargus haffara from Suez Bay using the method of Pauly, 1983 


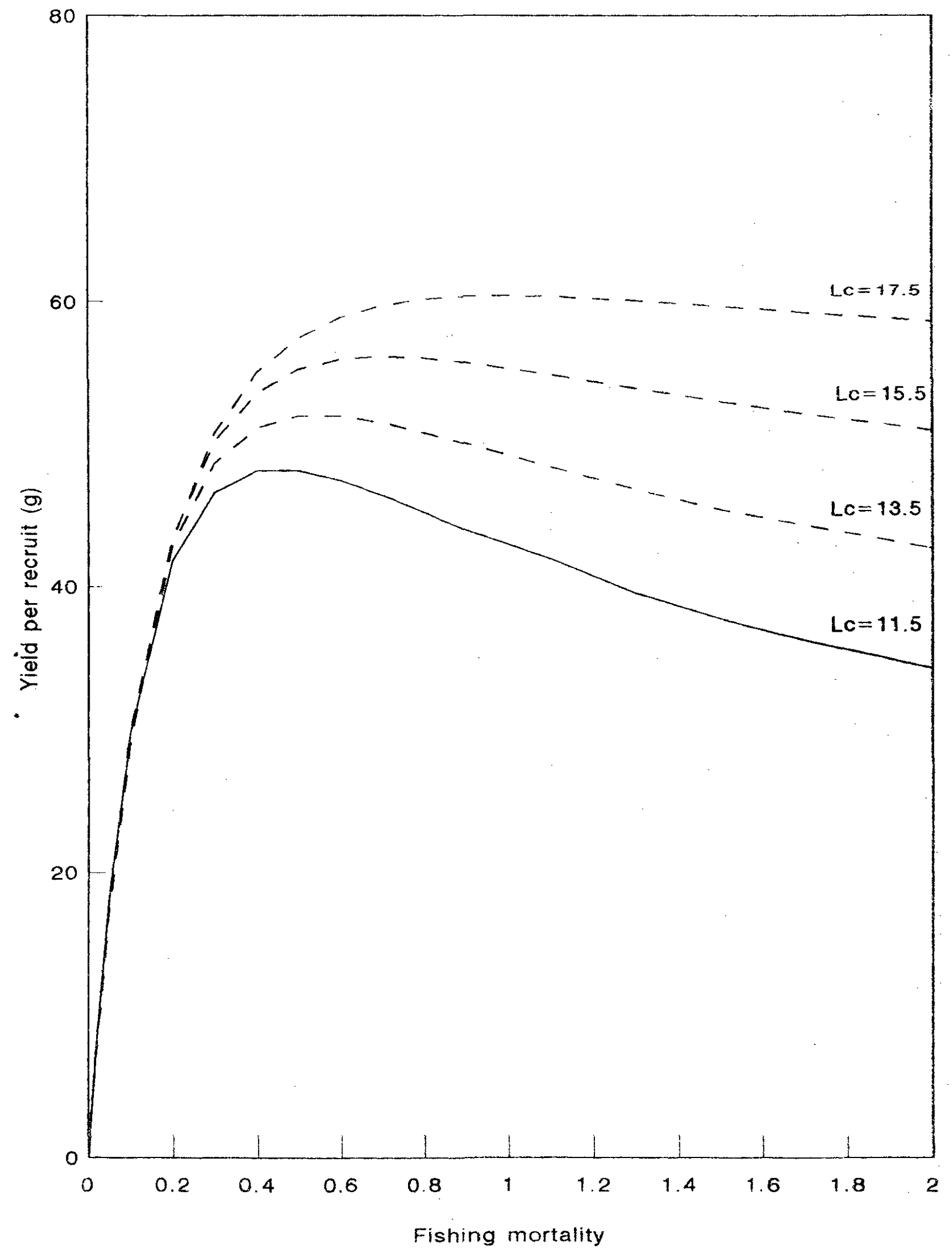

Fig. (9). Yield per recruit of Rhabdosargus haffara as a function of fishing mortality and length at first capture. 